\title{
Solid fermentation of wheat bran for hydrolytic enzymes production and saccharification content by a local isolate Bacillus megatherium
}

\author{
Reda M El-Shishtawy ${ }^{1 *}$, Saleh A Mohamed ${ }^{2 *}$, Abdullah M Asiri ${ }^{1,3}$, Abu-bakr M Gomaa ${ }^{4}$, Ibrahim H Ibrahim²
} and Hasan A Al-Talhi ${ }^{2}$

\begin{abstract}
Back ground: For enzyme production, the costs of solid state fermentation (SSF) techniques were lower and the production higher than submerged cultures. A large number of fungal species was known to grow well on moist substrates, whereas many bacteria were unable to grow under this condition. Therefore, the aim of this study was to isolate a highly efficient strain of Bacillus sp utilizing wheat bran in SSF and optimizing the enzyme production and soluble carbohydrates.

Results: A local strain Bacillus megatherium was isolated from dung sheep. The maximum production of pectinase, xylanase and a-amylase, and saccharification content (total soluble carbohydrates and reducing sugars) were obtained by application of the B. megatherium in SSF using wheat bran as compared to grasses, palm leaves and date seeds. All enzymes and saccharification content exhibited their maximum production during $12-24 \mathrm{~h}$, at the range of 40-80\% moisture content of wheat bran, temperature $37-45^{\circ} \mathrm{C}$ and $\mathrm{pH} 5-8$. An ascending repression of pectinase production was observed by carbon supplements of lactose, glucose, maltose, sucrose and starch, respectively. All carbon supplements improved the production of xylanase and a-amylase, except of lactose decreased a-amylase production. A little increase in the yield of total reducing sugars was detected for all carbon supplements. Among the nitrogen sources, yeast extract induced a significant repression to all enzyme productivity. Sodium nitrate, urea and ammonium chloride enhanced the production of xylanase, a-amylase and pectinase, respectively. Yeast extract, urea, ammonium sulphate and ammonium chloride enhanced the productivity of reducing sugars.
\end{abstract}

Conclusions: The optimization of enzyme production and sccharification content by B. megatherium in SSF required only adjustment of incubation period and temperature, moisture content and initial $\mathrm{pH}$. Wheat bran supplied enough nutrients without any need for addition of supplements of carbon and nitrogen sources.

Keywords: Bacillus megatherium, Enzymes, Saccharification, Solid fermentation

\section{Background}

Agricultural residues have an enormous potential as renewable carbon and energy sources. The main potential applications of agricultural residues are in food, animal feed, biofuel and pharmaceutical industries. Saccharification of agricultural residues by microbial hydrolytic enzymes (cellulases, xylanases, amylases and pectinases) is the first

\footnotetext{
* Correspondence: elshishtawy@hotmail.com; saleh38@hotmail.com ${ }^{1}$ Chemistry Department, Faculty of Science, King Abdulaziz University, P.O. Box 80203, Jeddah 21589, Saudi Arabia

${ }^{2}$ Biochemistry Department, Faculty of Science, King Abdulaziz University, Jeddah, Kingdom of Saudi Arabia

Full list of author information is available at the end of the article
}

step of bioconversion of organic material into reducing sugars, like glucose and xylose [1]. In the saccharification of agricultural residues, a potential effect was detected in presence of two or more enzymes [2]. Cellulases for cellulose hydrolysis [2], xylanases for hemicelluloses hydrolysis [3], amylase for amylose hydrolysis [4] and pectinase for pectin hydrolysis [5] are cooperatively needed in the saccharification of agricultural residues. The reducing sugars obtained from these hydrolyzing actions could be utilized as carbon and energy sources in the fermentation industry, such as lactic acid [6], hydrogen [7] and ethanol [8]. In addition, microbial hydrolytic enzymes utilized in 
several applications, such as food, textile, paper, pulp and detergent industries [9-12].

Solid state fermentation (SSF) is the growth of organisms on moist substrates in the absence of free-flowing water. The use of SSF for production of enzymes and other products has many advantages over submerged fermentation [13]. These advantages included: easier recovery of products, the absence of foam formation and smaller reactor volumes. Moreover, contamination risks are significantly reduced due to the low water contents and, consequently, the volume of effluents decreases. Another very important advantage is that, it permits the use of agricultural and agro-industrial residues as substrates which are converted into products with high commercial value like secondary metabolites [13,14]. Furthermore, the utilization of these compounds helps in solving pollution problems, which otherwise cause their disposal [15]. For enzyme production, the costs of these techniques are lower and the production is higher than submerged cultures [16,17]. A large number of fungal species was known to grow well on moist substrates in the absence of free-flowing water, whereas many bacteria are unable to grow under this condition [18-21]. As a result, most studies involving SSF have been conducted by using fungi. However, there are little reports of bacterial strains being used successfully for the production of enzymes by using SSF $[4,5,22,23]$. Therefore, the aim of this study is to isolate strain of Bacillus sp. capable of using wheat bran in SSF to produce $\alpha$-amylase, xylanase and pectinase. The saccharification content, total soluble carbohydrates and reducing sugars, of wheat bran was studied. Studies on optimizing production of enzymes and saccharification content were also carried out.

\section{Methods}

\section{Isolation, identification and efficiency of the cellulose decomposing bacilli}

Five isolates of Bacillus spp. were isolated from different samples i.e., sheep dung, horses waste, manure compost and rhizosphere soil. The efficiency of the five strains in cellulose decomposion was estimated using caboxymethyl cellulose (CMC) agar medium containing $\mathrm{g} / \mathrm{l}$ : $\mathrm{CMC}$, 5; peptone, $5 ; \mathrm{NaCl}, 5$; beef extract, 3; agar, 18 and $\mathrm{pH}$ was adjusted to 7 [24]. The most efficient strain in cellulose decomposion was identified according to Bergey's Manual of Systematic Bacteriology [25]. The highest efficient strain in cellulose decomposion was isolated from sheep dung and identified as B. megatherium.

\section{Agricultural residues}

Four dried agricultural residues, i.e. wheat bran, date seeds, grass and palm leaves were used as substrates for solid state fermentation (SSF).

\section{Physicochemical parameters of SSF}

Physicochemical parameters of SSF were studied for optimization production conditions of soluble carbohydrates, reducing sugars, $\alpha$-amylase, pectinase and xylanase by $B$. megatherium. The agricultural residues were sperately sterilized in an autoclave for $20 \mathrm{~min}$ at $121^{\circ} \mathrm{C}$. B. megatherium was grown in $50 \mathrm{ml}$ Erlenmeyer flask included $5 \mathrm{~g}$ of the respective sterilized agricultural residue and appropriate amount of water needed to adjust the moisture of dried substrate, which contained $10 \%$ moisture after dring. Optimized physicochemical parameters including: incubation period, incubation temperature, and moisture content of the substrate and incubation $\mathrm{pH}$. The $\mathrm{pH}$ was adjusted using $0.1 \mathrm{M} \mathrm{NaOH}$ or $\mathrm{HCl}$. The influence of supplementation of carbon sources (glucose, maltose, starch, sucrose, and lactose at $1 \% \mathrm{w} / \mathrm{v}$ ) and nitrogen sources (yeast extract, urea, sodium nitrate, ammonium sulphate, and ammonium chloride at $1 \% \mathrm{w} / \mathrm{v}$ ) has been studied. Each experiment was done in triplicate.

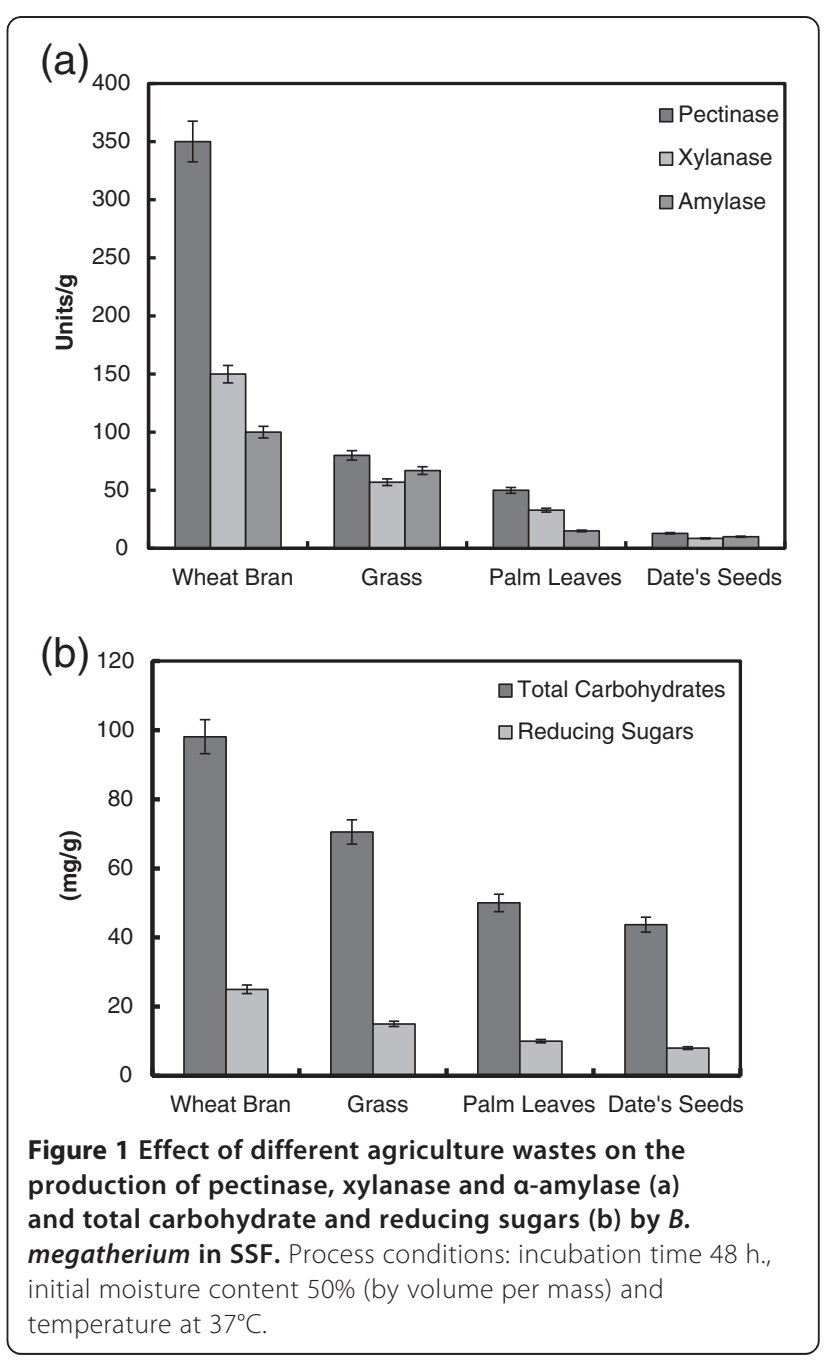




\section{Soluble carbohydrate and enzyme extraction}

Soluble carbohydrate and enzyme were extracted by mixing the fermented substrate with $50 \mathrm{ml}$ distilled water and shaked on a rotary shaker at $180 \mathrm{rpm}$ overnight. The suspension was then centrifuged at $12000 \mathrm{rpm}$ for $10 \mathrm{~min}$ and the supernatant was designated as a crude extract.

\section{Determination of total reducing sugars}

Total reducing sugars were determined by the method of Miller [26]. The reaction mixture contained $0.5 \mathrm{ml}$ of crude extract and $0.5 \mathrm{ml}$ dinitrosalicylic acid reagent. The tubes were heated in a boiling water bath for $10 \mathrm{~min}$. After cooling to room temperature, the absorbance was measured at $560 \mathrm{~nm}$. Glucose served as the calibration standard for total reducing sugar determination.

\section{Determination of total soluble carbohydrates}

Total soluble carbohydrates were determined by the method of Dubois et al. [27]. The reaction mixture contained $25 \mu \mathrm{l}$ of a 4:1 mixture of phenol and water, $0.8 \mathrm{ml}$ of crude extract and $2 \mathrm{ml}$ of concentrated sulfuric

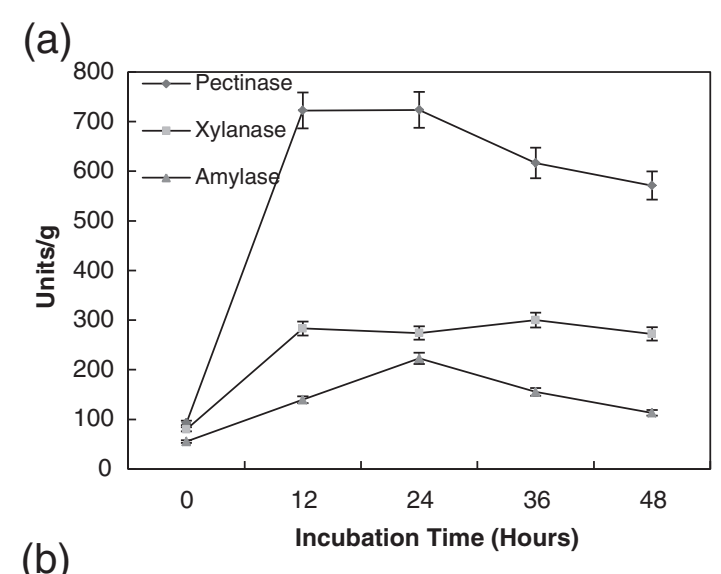

(b)

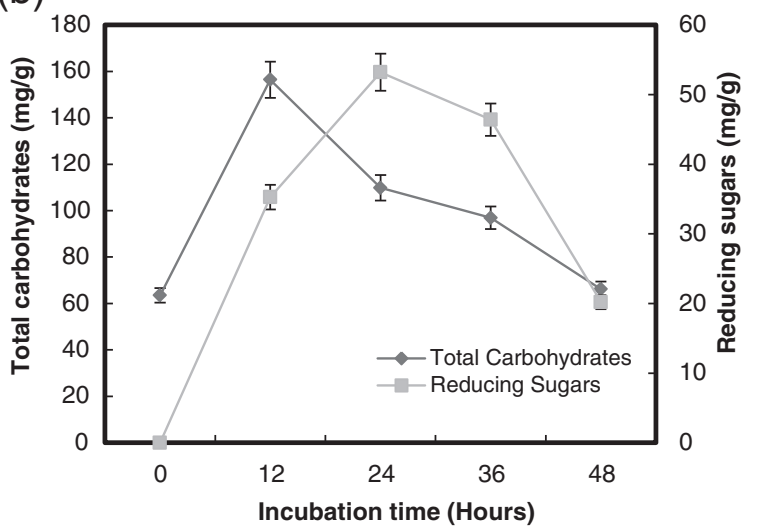

Figure 2 Effect of incubation time on the production of pectinase, xylanase and a-amylase (a), and total carbohydrate and reducing sugars (b) by $B$. megatherium in SSF using wheat bran as substrate. Process conditions: initial moisture content $50 \%$ (by volume per mass) and temperature at $37^{\circ} \mathrm{C}$. acid. Then mixed well, and heated in a boiling water bath for $30 \mathrm{~min}$. The absorbance was determined at $480 \mathrm{~nm}$. Glucose served as the calibration standard for total carbohydrate determination.

\section{Enzymes assays}

$\alpha$-Amylase, pectinase and xylanase activities were assayed by determining the liberated reducing end products using maltose, galacturonic acid and xylose as standards, respectively [26]. Substrates used were starch, polygalacturonic acid and birchwood xylan for $\alpha$-amylase, pectinase and xylanase, respectively. The reaction mixture $(0.5 \mathrm{ml})$ contained $1 \%$ substrate, $0.05 \mathrm{M}$ sodium acetate buffer $\mathrm{pH} 5.5$ and $0.1 \mathrm{ml}$ crude extract. Assays were carried out at $37^{\circ} \mathrm{C}$ for $1 \mathrm{~h}$. Then $0.5 \mathrm{ml}$ dinitrosalicylic acid reagent was added to each tube. Then the reaction mixture was mixed well, and heated in a boiling water bath for $10 \mathrm{~min}$. After cooling to room temperature, the absorbance was measured at $560 \mathrm{~nm}$. One unit of enzyme activity is defined as the amount of enzyme which liberated one $\mu \mathrm{mol}$ of reducing sugar per min under standard assay conditions.

All the experimental work was run in triplicates.
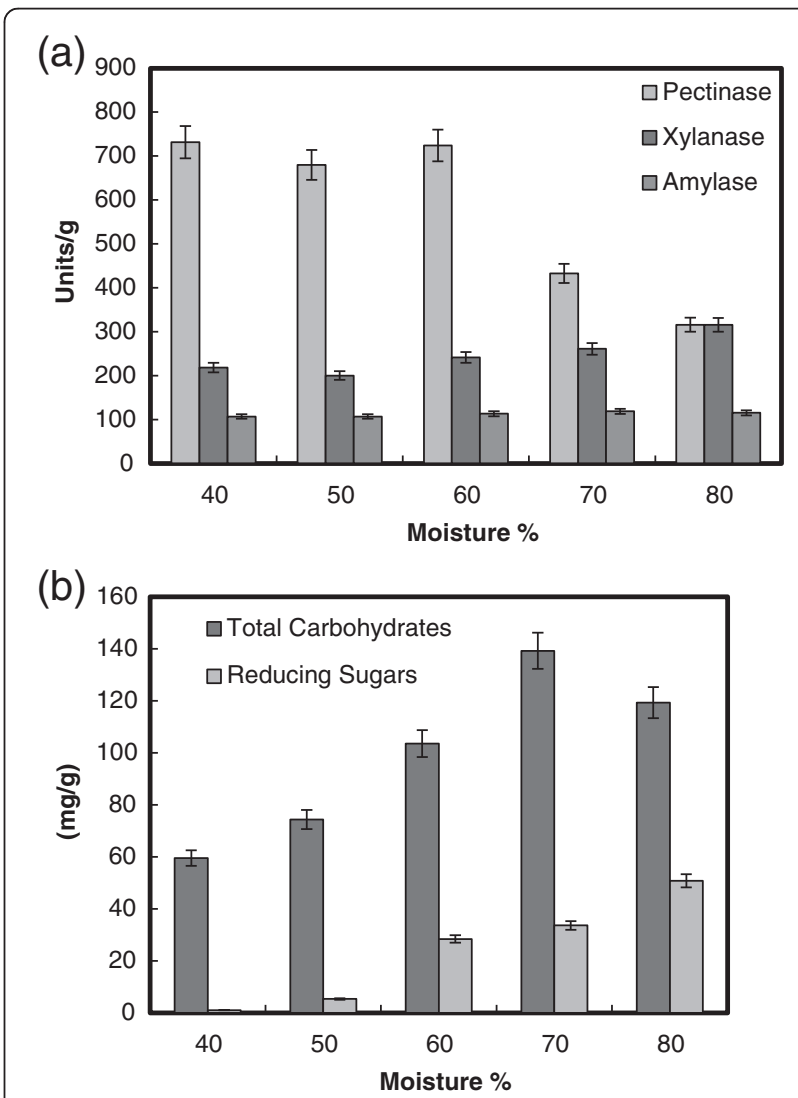

Figure 3 Effect of moisture \% on the production of pectinase, xylanase and a-amylase (a), and total carbohydrate and reducing sugars (b) by $B$. megatherium in SSF using wheat bran as substrate. Process conditions: incubation times $48 \mathrm{~h}$ and temperature at $37^{\circ} \mathrm{C}$. 


\section{Statistical analysis}

The obtained data were statistically analyzed as a randomized complete block design with three replicates by analysis of variance (ANOVA) using the statistical package software SAS (SAS Institute Inc., 2000, Cary, NC., USA). Comparisons between means were made by $F$-test and the least significant differences (LSD) at level $P=0.05$. Correlations coefficient among the different parameters were also calculated by SAS.

\section{Results and discussion}

\section{The effect of agricultural residues}

Production of pectinase, xylanase and $\alpha$-amylase, and saccharification content (total soluble carbohydrates and reducing sugars) by $B$. megatherium were tested in different SSF sources using wheat bran, grasses, palm leaves and date seeds. Figure 1a showed the maximum production of pectinase, xylanase and $\alpha$-amylase by $B$. megatherium (350, 150 and 100 units/g solid, respectively) in SSF using wheat bran as compared to other agriculture residues. The saccharification content of these agricultural residues improved these results, whereas the productivity of total soluble carbohydrates and reducing sugars exhibited maximum production by using wheat bran (Figure 1b). Similarly, among the lignocellulosic substrates tested, wheat bran gave maximum yield of xylanase by Cellulosimicrobium sp. as compared to other substrates viz. gram bran, rice husk, rice bran, wood dust and apple pomace [28]. The best substrate for xylanase production was wheat bran due to its nutritional content and large surface area [29], where wheat bran contained xylan and protein, which were served as carbon and nitrogen sources for microorganisms, respectively [30]. $\alpha$-Amylase was also exhibited the maximum production by Clostridium thermosulforegenes using wheat bran [31]. Wheat bran characterized by its better air circulation, loose particle binding and efficient penetration by mycelia and cheaper, therefore it showed a better prospect economically in fermentation processes [32]. Therefore, physicochemical parameters of SSF using wheat bran for optimization production of enzymes and saccharification content of $B$. megatherium was performed in the following study.

\section{The effect of incubation period}

Figure $2 \mathrm{a}$ showed the effect of incubation period on production of pectinase, $\alpha$-amylase and xylanase by B. megatherium grown on wheat bran in SSF. Pectinase, $\alpha$-amylase and xylanase exhibited their maximum production after

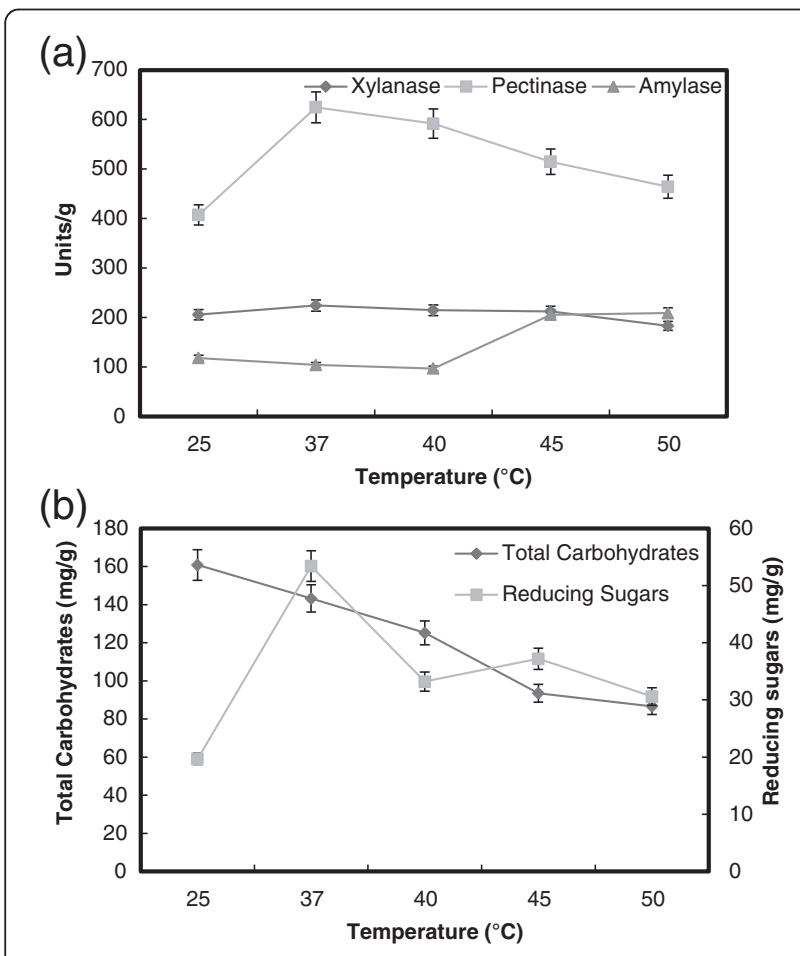

Figure 4 Effect of incubation temperature on the production of pectinase, xylanase and a-amylase (a), and total carbohydrate and reducing sugars (b) by $B$. megatherium in SSF using wheat bran as substrate. Process conditions: incubation times $48 \mathrm{~h}$ and initial moisture content $50 \%$ (by volume per mass).
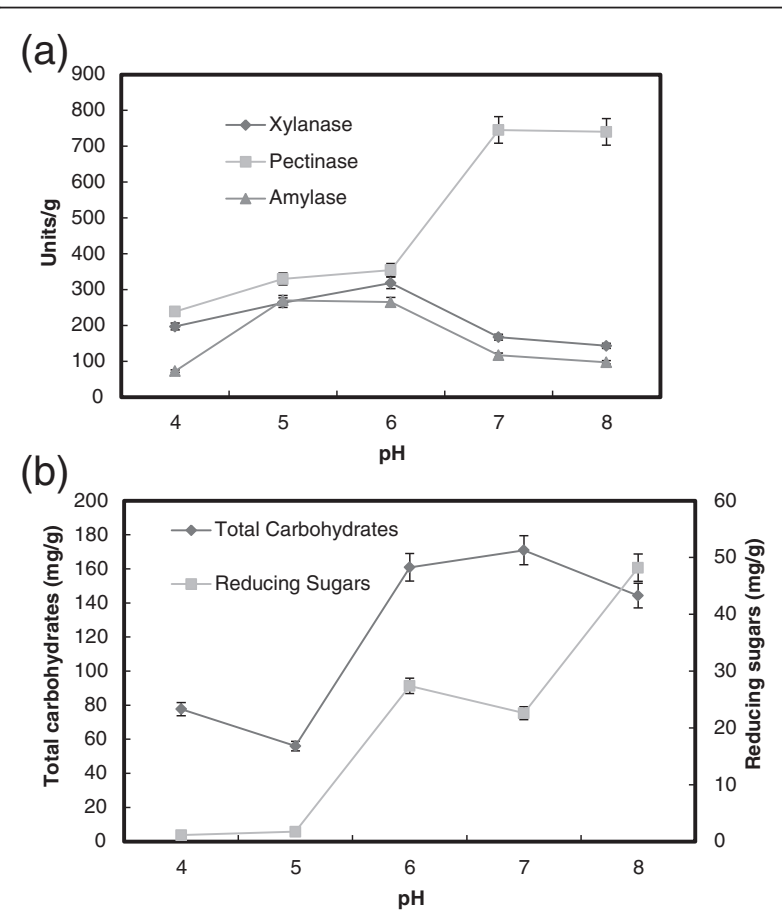

Figure $5 \mathrm{Effect}$ of $\mathrm{pH}$ on the production of pectinase, xylanase and a-amylase (a), and total carbohydrate and reducing sugars (b) by $B$. megatherium in SSF using wheat bran as substrates. Process conditions: incubation times $48 \mathrm{~h}$, initial moisture content 50\% (by volume per mass) and temperature at $37^{\circ} \mathrm{C}$. 
$24 \mathrm{~h}$ (720, 220 and 280 units/g solid, respectively). The maximum production of total soluble carbohydrates (160 mg/g solid) and reducing sugars (55 mg/g solid) was detected after 12 and $24 \mathrm{~h}$, respectively (Figure $2 \mathrm{~b}$ ). The maximum production of reducing sugars was inagreement with the maximum production of enzymes. Similarly, the maximum activity of $\alpha$-amylase was noted in enzyme extracts harvested after $24 \mathrm{~h}$ of SSF B. subtilis [33]. The formation of xylanase started from $18 \mathrm{~h}$ and reached its maximum after $72 \mathrm{~h}$ by Bacillus sp. [34]. B. licheniformis produced maximum of pectinase after $48 \mathrm{~h}$ [5].

\section{The effect of initial moisture content}

In SSF, the moisture content is an important factor that influences the growth and product yield of microbes [35]. Moisture is reported to cause swelling of the substrates, thereby facilitating better utilization of the substrate by microorganisms [36,37]. The data presented in t Figure 3a, clearly indicated a maximum production of the enzymes pectinase (720 units/g solid), xylanase (310 units/g solid) and $\alpha$-amylase (115 units/g solid) by B. megatherium at 40,
80 and $70 \%$ moisture, respectively. In addition, the maximum saccharification content of total soluble carbohydrates $(140 \mathrm{mg} / \mathrm{g}$ solid) and reducing sugars $(55 \mathrm{mg} / \mathrm{g}$ solid) was observed at 70 and $80 \%$ moisture, respectively (Figure 3b). Other results showed that the yield of $\alpha-$ amylase and amylopullulanase by Clostridium thermosulfurogenes increased with an increase in solid to moistening agent ratio from 1:0.5 to 1:2.5 (30 to 75\%) with a maximum at 1:2.25 (73\%) [31]. Optimum xylanase production from Bacillus sp. PKD-9 was observed when wheat bran was used at 1:4 ratio of solid substrate-to-moisture [23]. Any further increase in the ratio resulted in the decrease of enzyme yields may be due to clumping of solid particles which results in the decrease of interparticle space and diffusion of nutrients [29,37]. In contrast, the low moisture content leads to the decreased solubility of nutrients present in the wheat bran thereby decreased enzyme yields [38].

\section{The effect of incubation temperature}

The usual temperature maintained in SSF systems is in the range of $25-32^{\circ} \mathrm{C}$, depending on the growth kinetics

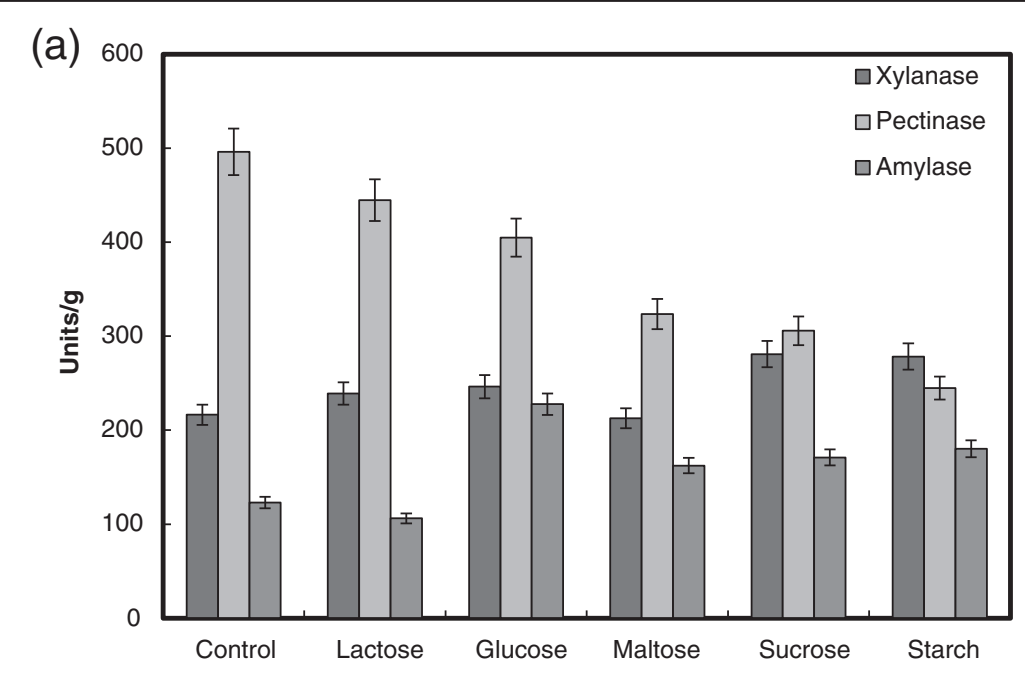

(b)

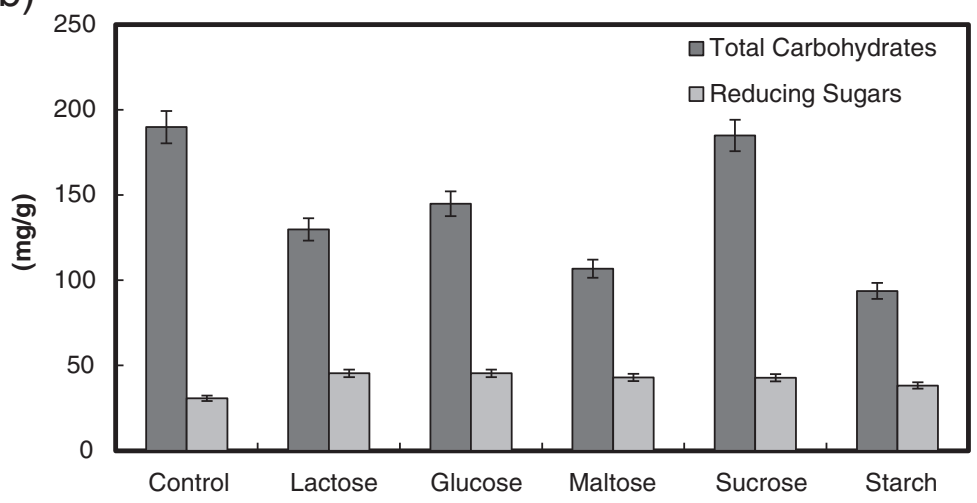

Figure 6 Effect of carbon source (1\%) supplementation on the production of pectinase, xylanase and a-amylase (a), and total carbohydrate and reducing sugars (b) by $B$. megatherium in SSF using wheat bran as substrates. 
of microorganism employed for fermentation purposes [39]. In the present study, the maximum production of both pectinase (620 units/g solid) and xylanase (220 units/g solid) by B. megatherium was achieved at $37^{\circ} \mathrm{C}$, and $45^{\circ} \mathrm{C}$ for $\alpha$-amylase (220 units/g solid) (Figure $4 \mathrm{a}$ ). These results were confirmed by maximum saccharification content of reducing sugars $\left(54 \mathrm{mg} / \mathrm{g}\right.$ solid) at $37^{\circ} \mathrm{C}$, where the maximum of total soluble carbohydrates (160 mg/g solid) was detected at $25^{\circ} \mathrm{C}$ (Figure 4b). In other study, the optimum temperature recorded for maximum growth and $\alpha$-amylase production by $B$. subtilis was $35^{\circ} \mathrm{C}$ [33]. Maximum production of pectinase and xylanase were obtained by B. licheniformis [5] and Bacillus sp. PKD-9 [23] at $37^{\circ} \mathrm{C}$ in solid wheat bran.

\section{The effect of $\mathrm{pH}$}

The initial $\mathrm{pH}$ of fermentation medium has a significant effect on bacterial growth and enzyme production [40]. In order to study the effect of $\mathrm{pH}$ on enzyme production and saccharification content of wheat bran by $B$. megatherium, the production medium having $\mathrm{pH}$ 's ranged from 4 to 8 . Figure 5 a shows a maximum production of pectinase (750 units/g solid), xylanase (280 units/g solid) and $\alpha$-amylase (250 units/g solid) by $B$. megatherium at $\mathrm{pH} \mathrm{7,6}$ and 5, respectively. The high activity of pectinase results was reinforced by maximum saccharification content of total soluble carbohydrates $(170 \mathrm{mg} / \mathrm{g}$ solid $)$ and reducing sugars (50 mg/g solid) and at $\mathrm{pH} 7-8$ (Figure $5 \mathrm{~b}$ ). However, most of Bacillus species were found to be produce maximum pectinase at different $\mathrm{pH}$ 's ranging from 7 to 9 [41]. Further, the type of buffer used in nutrient solution is a key factor in governing $\alpha$-amylase production by the B. subtilis.

\section{The effect of supplementation carbon and nitrogen sources}

The influence of supplementary carbon sources such as starch, sucrose, maltose, lactose or glucose at $1 \%$ (by
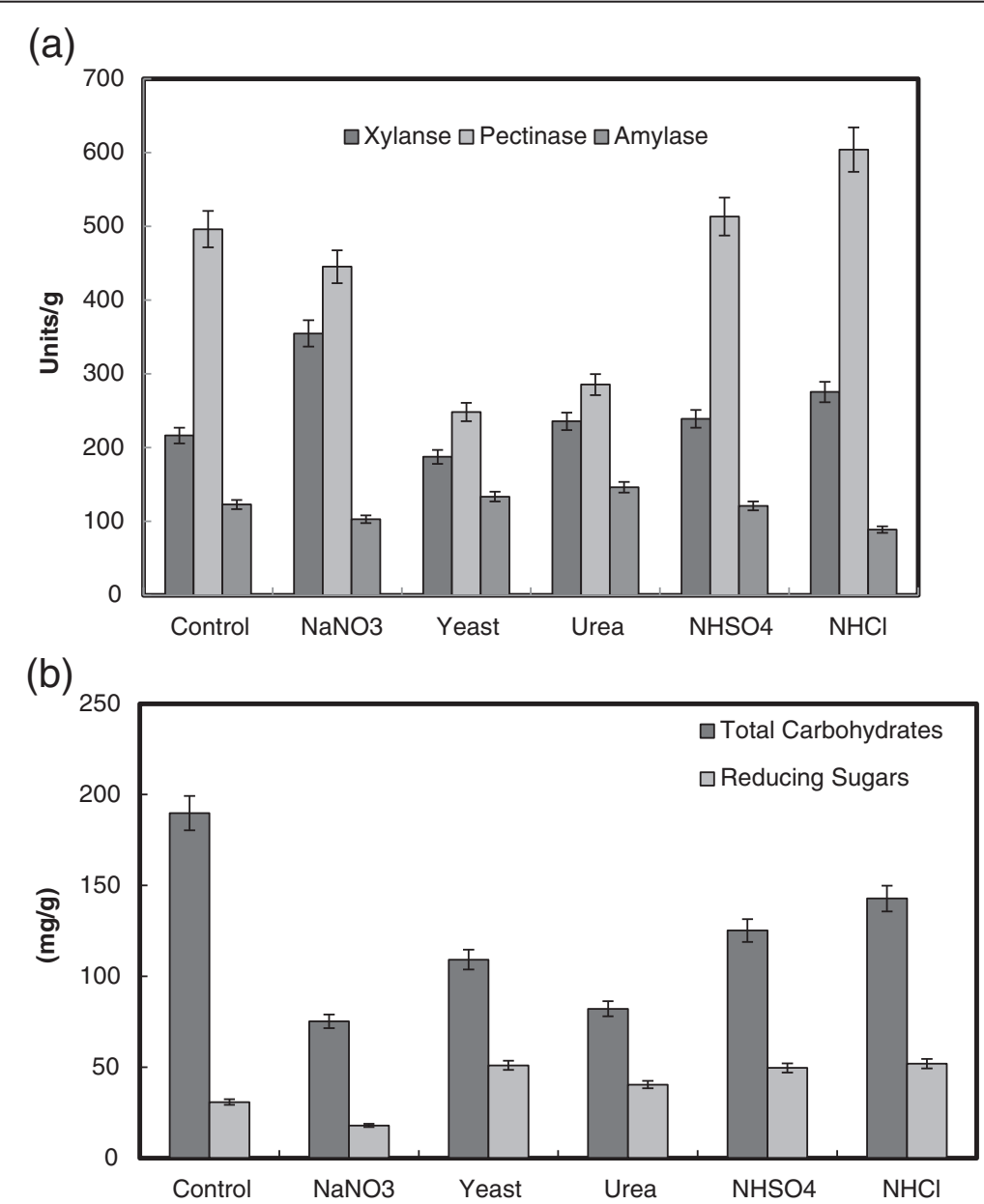

Figure 7 Effect of nitrogen source (1\%) supplementation on the production of pectinase, xylanase and a-amylase (a), and total carbohydrate and reducing sugars (b) by $B$. megatherium in SSF using wheat bran as substrates. Process conditions: incubation times $48 \mathrm{~h}$, initial moisture content $50 \%$ (by volume per mass) at temperatures $37^{\circ} \mathrm{C}$. 
mass) to wheat bran on production of pectinase, xylanase and $\alpha$-amylase by B. megatherium was studied (Figure 6a). An ascending inhibition of pectinase production by lactose, glucose, maltose, sucrose and starch was detected, respectively. However, all carbon supplements improved the production of xylanase and $\alpha$-amylase, except of lactose decreased $\alpha$-amylase production. While most of carbon supplements exhibited repressive effect on the production of total soluble carbohydrates except of sucrose, a little increase in the yield of total reducing sugars was detected (Figure 6b). The same carbon supplements except starch caused repressive effect on pectinase production by $B$. licchenformis [5]. Supplementation of carbon sources increased $\alpha$-amylase production by $B$. cereus during SSF using wheat bran [22]. B. thermooleovorans is reported to prefer starch, glucose, lactose, maltose and maltodextrins as carbon sources for $\alpha$-amylase secretion $[42,43]$. In contrast, carbon sources such as glucose, maltose and starch did not enhance $\alpha$-amylase production by thermophilic $B$. coagulans in solid-state fermentation using wheat bran [29]. Xylanase production by Bacillus sp. AR-009 grown on wheat bran was repressed upon addition of lactose, glucose and sucrose [3].

Studies on supplementation of nitrogen sources such as ammonium sulphate, ammonium nitrate, ammonium chloride, yeast extract or urea at $1 \%$ concentration to the wheat bran showed various effects on pectinase, xylanase and amylase production by B. megatherium (Figure 7a). Among the nitrogen sources, yeast extract induced a significant repression to all enzyme productivity. While sodium nitrate inhibited $\alpha$-amylase production from 123 to103 units/g, it enhanced xylanase production from 216 to 355 units/g. Urea on the other hand inhibited production of xylanase and enhanced $\alpha$-amylase. Also, a significant enhancement of pectinase activity was obtained by ammonium chloride supplementation from 496 to 610 units/g. While all nitrogen sources inhibited the production of total soluble carbohydrates, yeast extract, urea, ammonium sulphate and ammonium chloride enhanced the productivity of the total reducing sugars (Figure 7b). Hashemi et al. [4] reported that ammonium nitrate was the best inducer for $\alpha$-amylase secretion followed by yeast extract 'by Bacillus sp. On the other hand, the limitation or starvation of nitrogen during the fermentation resulted in the limited growth of B. subtilis and the enhancement of $\alpha$-amylase production [44]. For Bacillus sp. AR-009, yeast extract increased xylanase production [3]. Maximum production of pectinase was achieved when yeast extract was used in fermentation medium [5].

\section{Conclusions}

In conclusion, the production of pectinase, xylanase and amylase and saccharification content (total soluble carbohydrates and reducing sugars) by a newly local isolat B. megatherium using wheat bran in SSF will have several advantages. The optimization of enzyme production and sccharification content required only adjustment of incubation time and temperature, moisture content and initial $\mathrm{pH}$. Wheat bran supplied enough nutrients without any need for addition of supplements of carbon and nitrogen sources. All these combined together could greatly reduce the overall cost of production of enzymes and saccharification content by B. megatherium. In the future, the reducing sugars will be used for hydrogen production.

\section{Competing interests}

The authors declare that they have no competing interests.

\section{Authors' contributions}

El-R, MS, AA, GM, II and AL-H performed all experiments and read and approved the final manuscript.

\section{Acknowledgement}

This Project was funded by the King Abdulaziz City for Science and Technology (KACST) under grant number 11-ENE1527-03. The authors, therefore, acknowledge with thanks KACST for support for Scientific Research. Also, the authors are appreciating the kind cooperation provided by the Deanship of Scientific Research (DSR), King Abdulaziz University.

\section{Author details}

${ }^{1}$ Chemistry Department, Faculty of Science, King Abdulaziz University, P.O. Box 80203, Jeddah 21589, Saudi Arabia. ${ }^{2}$ Biochemistry Department, Faculty of Science, King Abdulaziz University, Jeddah, Kingdom of Saudi Arabia. ${ }^{3}$ The Center of Excellence for Advanced Materials Research, King Abdulaziz University, Jeddah 21589, Saudi Arabia. ${ }^{4}$ Biology Department, Faculty of Science, King Abdulaziz University, Jeddah, Kingdom of Saudi Arabia.

Received: 24 February 2014 Accepted: 16 April 2014

Published: 24 April 2014

\section{References}

1. Howard RL, Abotsi E, Jansen van REL, Howard S: Lignocellulose biotechnology: issues of bioconversion and enzyme production. Afric J Biotechnol 2003, 2:602-619.

2. Mansfield SD, Mooney C, Saddler JN: Substrate and enzyme characteristics that limit cellulose hydrolysis. Biotechnol Prog 1999, 15:804-816.

3. Gessesse A, Mamo G: High level xylanase production by an alkalophilic Bacillus sp. by using solid state fermentation. Enzyme Microb Technol 1999, 25:68-72.

4. Hashemi M, Razavi SH, Shojaosadati SA, Mousavi SM, Khajeh K, Safari M: Development of a solid-state fermentation process for production of an alpha amylase with potentially interesting properties. J Biosci Bioeng 2010, 110:333-337.

5. Ur Rehman H, Qader SAU, Aman A: Polygalacturonase: production of pectin depolymerising enzyme from bacillus licheniformis KIBGE IB-21. Carbohydr Polym 2012, 90:387-391.

6. Anuradha R, Suresh AK, Venkatesh KV: Simultaneous saccharification and fermentation of starch to lactic acid. Process Biochem 1999, 35:367-375.

7. Kapdan IK, Kargi F: Review biohydrogen production from waste materials. Enzyme Microb Technol 2006, 38:569-582.

8. Sun Y, Cheng J: Hydrolysis of lignocellulosic materials for ethanol production: A review. Bioresour Technol 2002, 83:1-11.

9. Bhat MK, Bhat S: Cellulose degrading enzymes and their potential industrial applications. Biotechnol Adv 1997, 15:583-620.

10. Beg QK, Kapoor M, Mahajan L, Hoondal GS: Microbial xylanases and their industrial applications: a review. Appl Microbiol Biotechnol 2001, 56:326-338.

11. Hoondal GS, Tiwari RP, Tiwari R, Dahiya N, Beg QK: Microbial alkaline pectinases and their industrial application: A review. Appl Microbiol Biotechnol 2002, 59:409-418. 
12. Sivaramakrishnan S, Gangadharan D, Nampoothiri KM, Soccol CR, Pandey A: Alpha-amylases from microbial sources-an overview on recent development. Food Technol Biotechnol 2006, 44:173-184.

13. Lonsane BK, Ramesh MV: Production of bacterial thermostable a-amylase by solid-state fermentation: a potential tool for achieving economy in enzyme production and starch hydrolysis. Adv Appl Microbiol 1990, 35:1-56.

14. Pandey A: Recent process developments in solid-state fermentation. Process Biochem 1992, 27:109-117.

15. Couto SR, Sanroman MA: Application of solid-state fermentation to food industry - a review. J Food Eng 2005, 22:211-219.

16. Pandey A: Aspects of fermenter design for solid-state fermentations. Process Biochem 1991, 26:355-361.

17. Sukumaran RK, Singhania RR, Mathew GM, Pandey A: Cellulase production using biomass feed stock and its application in lignocellulose saccharification for bio-ethanol production. Renew Energ 2009, 34:421-424.

18. Mohamed SA, Al-MalkiL AL, Khan JA, Kabli SA, Al-Garni SM: Solid state production of polygalacturonase and xylanase by Trichoderma species using cantaloupe and watermelon rinds. J Microbio/ 2013, 51:605-611.

19. Rahardjo YSP, Sie S, Weber FJ, Tramper J, Rinzema A: Effect of low oxygen concentrations on growth and a-amyase production of Aspergillus oryzae in model solid-state fermentation systems. Biomol Eng 2005, 21:163-172.

20. Ustok Fl, Canan Tari C, Gogus N: Solid-state production of polygalacturonase by Aspergillus sojae ATCC 20235. J Biotechnol 2007, 127:322-334.

21. Senthilkumar SR, Ashokkumar B, Raj KC, Gunasekaran P: Optimization of medium composition for alkali-stable xylanase production by Aspergillus fischeri Fxn 1 in solid-state fermentation using central composite rotary design. Bioresour Technol 2005, 96:1380-1386.

22. Singh RK, Mishra SK, Kumar N: Optimization of a-amylase production on agriculture byproduct by Bacillus cereus MTCC 1305 using solid state fermentation. Res J Pharm Biol Chem Sci 2010, 1:867-876.

23. Panwar D, Srivastava PK, Kapoor M: Production, extraction and characterization of alkaline xylanase from Bacillus sp. PKD-9 with potential for poultry feed. Biocatal Agric Biotechnol 2014, 3:118-125.

24. Teather RM, Wood PJ: Use of congo red-polysaccharide interactions in enumeration and characterization of cellulytic bacteria from the bovine rumen. Appl Environ Microbiol 1982, 43:777-780.

25. Bergey JG, Holt NR, Krieg PHA: Bergey's Manual of Determinative Bacteriology, Lippincott Williams. 9th edition; 1994. ISBN ISBN 0-683-00603-7.

26. Miller GL: Use of dinitrosalicylic acid reagent for determination of reducing sugar. Anal Chem 1959, 31:426-429.

27. Dubois M, Gilles KA, Hamitton JK, Rebers PA, Smith F: Colorimeteric method for determination of sugars and related substances. Anal Chem 1956, 28:350-356.

28. Rajashri DK, Anandrao RJ: Optimization and scale up of cellulase-free xylanase production in solid state fermentation on wheat bran by Cellulosimicrobium sp. MTCC 10645. Jordan J Biol Sci 2012, 5:289-294.

29. Babu KR, Satyanarayana T: a-Amylase production by thermophilic Bacillus coagulans in solid-state fermentation. Process Biochem 1995, 30:305-309.

30. Thiago LR, Kellaway RC: Botanical composition and extent of lignification affecting digestibility of wheat and oat straw and pastalum hay. Animal Feed Sci Technol 1982, 7:71-81.

31. Mrudula S, Reddy G, Seenayya G: Effect of substrate and culture conditions on the production of amylase and pullulanase by thermophilic Clostridium thermosulforegenes SVM17 in solid state fermentation. Malays J Microbiol 2011, 7:19-25.

32. Malathi S, Chakraborti R: Productions of alkaline protease by a new Aspergillus flavus isolate under solid sustrate fermentation conditions for use as a depilation agent. Appl Environ Microbiol 1991, 57:712-716.

33. Unakal C, Kallur RI, Kaliwal BB: Production of a-amylase using banana waste by Bacillus subtilis under solid state fermentation. Eur J Exper Biol 2012, 2:1044-1052

34. Cordeiro CAM, Martins MLL, Luciano AB, da Silva RF: Production and properties of xylanase from Thermophilic Bacillus sp. Braz Arch Biol Technol 2002, 45:413-418.

35. Ramesh MV, Lonsane BK: Critical importance of moisture content of the medium in a-amylase by Bacillus licheniformis M27 in a solid-state fermentation system. Appl Microbiol Biotechnol 1990, 33:501-505.
36. Kim JH, Hosobuchi M, Kishimoto M, Seki T, Ryu DDY: Cellulase production by a solidstate culture system. Biotechnol Bioeng 1985, 27:1445-1450.

37. Nagendra PG, Chandrasekharan M: L-glutaminase production by marine Vibrio costicola under solid-state fermentation using different substrates. J Marine Biotechnol 1996, 4:176-179.

38. Feniksova RV, Tikhomirova AS, Rakhleeva BE: Conditions for forming amylase and proteinase in surface culture of Bacillus subtilis. Mikrobiologia 1960, 29:745-748.

39. Lonsane BK, Ghildyal NP, Budiatman S, Ramakrishna SV: Engineering aspects of solid state fermentation. Enzyme Microb Technol 1985, 7:258-265.

40. Murad HA, Saleem MME: Utilization of uf-permeate for producing exopolysaccharides from lactic acid bacteria. Mansoura Univ J Agric SCi 2001, 26:2167-2175.

41. Kobayashi T, Koike K, Yoshimatsu T, Higaki N, Suzumatsu A, Ozawa T, Hatada Y, Ito S: Purification and properties of a low-molecular weight, high-alkalinepectate lyase from an alkaliphilic strain of Bacillus. Biosci Biotechnol Biochem 1999, 63:65-72.

42. Narang S, Satyanarayana T: Thermostable a-amylase production by an extreme thermophilic Bacillus thermooleovorans. Lett Appl Microbiol 2001, 32:1-35.

43. Arunava B, Pal SC, Sen SK: Alpha amylase production in lactose medium by Bacillus circulanse. J Microbiol 1993, 9:142-148.

44. Mirminachi F, Zhang A, Roehr M: Citric acid fermentation and heavy metal ions: Effect of iron, manganese and copper. Acta Biotechnol 2000, 22:363-373.

doi:10.1186/1472-6750-14-29

Cite this article as: El-Shishtawy et al: Solid fermentation of wheat bran for hydrolytic enzymes production and saccharification content by a local isolate Bacillus megatherium. BMC Biotechnology 2014 14:29.

\section{Submit your next manuscript to BioMed Central and take full advantage of:}

- Convenient online submission

- Thorough peer review

- No space constraints or color figure charges

- Immediate publication on acceptance

- Inclusion in PubMed, CAS, Scopus and Google Scholar

- Research which is freely available for redistribution 